\title{
Præsteslægten Claudius.
}

\author{
Af Jonathan Smith.
}

I.

Som bekendt gik i de første Aarhundreder efter Reformationen Præstekaldene ofte i Arv fra Fader til Søn eller ogsaa til Svigersøn i flere Slægtled, saaledes at samme Præsteslægt var knyttet til samme Sogn i 100-200 Aar. De meste kendte slesvigske Præsteslægter er Monrad i Aastrup, Fabricius i Løjt, Brandt i Nordborg, Boysen og Zoëga i Vilstrup. Næppe saa meget kendt er Præsteslægten Claudius, som hvis man medregner en Svigerdatters anden Mand, som paa denne Maade fik Kaldet, sad som Praster i Emmerlev. fra 1598-1744.

Slægtens Stamfader er Claus Povlsen, som blev Præst i Emmerlev ved at agte sin Forgænger Peter Andersens Datter. Denne havde faaet Kaldet ved at gifte sig med Formandens Jens Jepsens Enke, som var en Datter af Hans Ditlevsen, Sognets forste Præst efter Reformationen. Saaledes kan Slægten ad Spindesiden føres tilbage til 1536, saa at Emmerlev Præstekald er gaaet i Arvi 200 Aar.

Foruden i Emmerlev sad Slægten Claudius i Nabosognene og i flere Sogne sỹdfor Tønder. En særlig Blomstring fik Slægten i S. Lygum, hvor den sad i ubrudt Række fra 1623-1720 og derefter atter fra 1787-1798. Da Præsten Claus Claudius døde i 1720, vilde Menigheden have hans Son Christian Detlev til Præst, men Kongen havde allerede udnævint en anden. Sognet sendte saa de Kirkeældste til Kobenhavn, de fik Foretræde hos Kongen, som efter at have hørt om den afdøde Sjælesørgers Nidkærhed, godt kunde forstaa deres Ønske om at faa Sønnen som hans Eftermand, men Kongens Udnævnelse kunde ikke gøres usket. Christian Detlev Claudius fik Adgang til at prædike for Kongen, som roste hans Prædiken og gav ham Løfte om det første ledige Embede i Slesvig. Han blev senere Præst i Flensborg, først dansk Præst ved Helligaandskirken og tilsidst Præst ved St. Nikolaj Kirken. 
Fra S. Lygum kom en af Slægten til Reinfeld i Holsten, ${ }^{\text {la) }}$ han hed Mathias Claudius og blev Fader til den kendte Forfatter Mathias Claudius, Udgiver af "Der Wandsbecker Bote". En anden Søn, Peter Claudius, var først Godsinspektør ved det Ashebergske Gods, senere blev han Ejer af Kathrinegaard i Tolk Sogn. Fra disse to Sønner nedstammer alle Præster af Navnet Claudius, som havde Kald i Hertugdømmerne i forrige Aarhundrede. Af Mathias Claudius Sønner blev den ældste Johannes Præst i Sahms i Lauenborg, August Ernst Carl i Blekendorf (Holsten) og Carl Peter Franziscus i Segeberg. En Søn af Peter Claudius: Johan Peter Gotthilf blev Prast i Burkal, hans Søn Peter Heinrich Carl blev Præst i Tolk og dennes Søn Wilhelm blev Præst i Neumünster, hvor han døde 1906. Med ham døde den sidste Præst af Slægten Claudius i Hertugdømmerne.

Af hele Slægten Claudius er kun et Medlem bleven Præst $i$ Kongeriget, det er Peter Claussøn, som var Præst i Eltang-Vilstrup fra 1681-1719. Han var Søn af Claus Claudius, som var Præst i Emmerlev fra 1650-1691. Efter sit Hjemsted kaldes Peter Claussøn sædvanlig Peter Emmerlev.

En Oversigt over de Præsteembeder, som Slægten sidder inde med, ser saaledes ud:

Emmerlev: Claus Povlsøn 1598-1650, Claus Claudius 1650-1691, Claus Claudius jr., Capellan 1675-1686, Markus Kiel 1691-1712, Johannes Claudius 1712-1744,

Hjerpsted: $\quad$ Petrus Claudius 16..-1649, Nicolaus Claudius 1724-1740,

Skast: Johannes Claudius $(1684,1693)$,

Daler: Jens Claudius 1634-1658,

Hostrup: Poul Claudius 1638-1665,

Burkal: Johann Peter Gotthilf Claudius 1838-1848,

Flensborg: Christian Detlev Claudius 1723-1756,

la) Angaaende hans Efterkommere se: Stammfolge des Geschlechtes Claudius ((Altona 1936). 
S. Lygum: Johannes Claudius 1623-1649,

Peter Claudius 1649-1682,

Claus Claudius 1682-1720,

Andreas Christian Claudius 1787-1798,

Brarup: Johannes Claudius 1667-1669,

Klangsbøl: Johannes Claudius 16..-1680,

Humptrup: $\quad$ Peter Claudius I $1649-16 \ldots$

Peter Claudius II 16..-1693,

Tolk: Peter Heinrich Carl Claudius 1864-1887,

Reinfeld: Mathias Claudius 1729-1773,

Blekendorf: $\quad$ Augustinus Ernst Carl Claudius 1821-1854,

Segeberg: $\quad$ Carl Peter Friedrich Claudius 1838-1865,

Neumünster: Wilhelm Claudius 1897-1906,

Sahms: Johannes Claudius 1813-1859,

Eltang-Vilstrup: Peter Clausen 1681-1719.

II.

Slægtens Stamfader Claus Povlsøn stammer formentlig fra Ribe. Han besøgte Latinskolen og blev Student i 1594. Han ordineredes den 9. April 1598 og ægtede samme Aar Ingeborg, Datter af Sognepræsten i Emmerlev Peter Andersen, som var død Aaret iforvejen, og fik paa denne Maade Kaldet.

Det var dengang Skik og Brug, at Studenternes Navne indførtes i Universitetets Fortegnelse paa Latin. Derved blev Claus Povlsøn til Claudius Pauli. Som Præst kaldtes han i officielle Skrivelser Dominus (Hr.) Claudius Paulinus.

Hans Børn hed efter hjemlig Navneskik Claussøn eller Clausdatter. Naar Sønnerne sendtes paa Universitetet, blev de indskrevne under Navneformen Claudii. Indbyrdes og hjemme vedblev de dog at kalde sig Claussøn. Først et senere Slægtled antog den latiniserede Navneform Claudius som Familienavn.

Ved Indskrivningen paa Universiteterne indfortes Studenten foruden med sit Fornavn (Døbenavn) og sit Fadersnavn ofte ogsaa med sin Hjemstedsbetegnelse, da dette var et bedre Skelnemærke end Faderbetegnelsen (Claussøn). Saa kunde Hjemstedsbetegnelsen blive Kaldenavn og gaa over til at bruges endda of- 
ficielt. Saaledes kaldes Peter Claussøn, som blev Præst i EltangVilstrup, i Præstekaldsbogen simpelthen Peter Emmerlev.

Paa en Træfrise i Eltang Kirkes Vaabenhus staar: Anno 1686 udi hæderlig Mands Hr. Peder Clavsen Emmerlefs Tider dette Pulpitur af ny opsæt, da var Hans Bertelsen og Jens Jørgens:2n af Lilballe Kirkens Værge.

Præsterne betegnedes dengang ved Titlen Hr. og Fornavnet, f Ex. Hr. Peder, denne Betegnelse giver ingen Oplysning om Præstens Afstamning. Hvis der i Universitetets Matrikel staar Petrus Claudii, saa ved vi, at Faderen hed Claus, og staar der andetsteds Peder Emmerlev, saa kan vi gaa ud fra, at vedkommende stammer fra Emmerlev. At Petrus Claudii og Peder Emmerlev er een og samme Person kan man ikke paa Forhaand vide noget om; det kan sandsynliggøres, hvis han optræder som Fadder i Familien; det er sjældent, at man ved en Indskrift som den ovennævnte faar Beviset for Identiteten.

Denne Skiften af Navngivningen mellem den danske Form, den latinske Form og Hjemstedsbetegnelsen gør det vanskeligt at hitte Rede $i$, hvem er hvem, og i flere Tilfælde maa man nøjes med Sandsynlighedsantagelser.

I det følgende skal der gøres Rede for nogle Identifikationer.

Claus Povlsøns ældste Søn hed Peter Claussøn, han immatrikuleredes Febr. 1620 ved Universitetet i Rostock som Petrus Claudii og 25/3 1621 i København under samme Navn. Samme Aar blev han ifl. O. H. Moller: Genealogia Claudiorum, Kapellan hos sin Fader. I Hjerpsted var der i 16... en Præst Petrus Claudius. Man kan sikkert gaa ud fra, at det var fornævnte Peter Claussøn. Ved Daaben af Claus Claussøns Datter Ingeborg d. 2. Marts 1649 nævnes blandt Fadderne Anna Pedersdaatter af Hierupsted, det var sikkert Broderdatteren. Peter Claussøn var formentlig endnu Præst i Hjerpsted paa dette Tidspunkt, to Aar efter døber hans Efterfølger Laurits Mauritius Claus Claussøns Søn Hans.

Man er hidtil gaaet ud fra, at Præsten i Hjerpsted Petrus Claudius er død ca. 1649. Men meget taler for, at han har over- 
taget Præstekaldet i Humptrup, hvor der paa dette Tidspunkt dukker en; Præst af samme Navn op. At denne Præst hørte til Emmerlev Slægten, fremgaar bl. a. af, at han var Døbefader til Claus Claussøns Søn Peter.

Om Præsterækken i Humptrup skriver H. N. A. Jensen ${ }^{1}$ ) følgende: "Petrus Claudius fra Hostrup fra 1649, ægtede Formandens Enke, levede endnu 1686i«.

Da den næste kendte Præst i Humptrup har tiltraadt Embedet i 1693, er man gaaet ud fra, at Præsten Petrus Claudius har haft Kaldet fra 1649-1693, og da han betegnes som værende fra Hostrup, formodede man, at denne Petrus Claudius maatte være en Søn af Poul Claudius, sorn var Præst i Hostrup fra 1638-1665, i dennes 2. Egteskab med Herlich, en Datter af Lorenz Jensen i Tønder. Ifl. Moller havde Povl Claudius forst været gift med Anna, en Datter af den i 1634 afdode Forgænger Riggel Petersen. Dette Fgteskab er formentlig indgaaet i 1638, hun døde i sin første Barselseng, altsaa 1639 eller 1640. Aggteskabet med Herlich kan derfor først være indgaaet i $1640 \mathrm{og}$ den i dette Agteskab fødte Søn Peter kan tidligst vare født i 1641. Da denne Peter Claudius var 9 Aar i 1650, kan han hverken have været Præst eller have indgaaet Agteskab med Eddo Jacobis Enke Cecilia, Datter af Raadmand Chr. Sønnichsen i Flensborg. Den eneste Peter Claudius, vi kender, som kunde beklæde Kaldet i Humptrup, er Præsten i Hjerpsted Peter Claussøn. Han nævnes senest 1649 i Hjerpsted og er der ikke mere i 1651. Da Hjerpsted er et af de mindste Kald, er det muligt, at han har søgt Humptrup. Og hvis han paa det givne Tidspunkt var Enkemand, var der ikke noget i Vejen for, at han kunde gifte sig med Formandens Enke og derved sikre sig Kaldet.

H. N. A. Jensen siger, at Præsten Petrus Claudius i Humptrup endnu levede 1686. Han maa enten have set ham omtalt paa dette Tidspunkt eller ogsaa maa han have set en Skri-

1) Versuch einer kirchlichen Statistik des Herzogthums Schleswig I, 476. 
velse af ham fra dette Tidspunkt. Det har dog næppe været det Testamente, som nu findes i Rigsarkivet som Indlæg til »Patenten " fra 1686. At det er bevaret, er dobbelt heldigt, fordi selve "Patenten « fra 1686 er gaaet tabt, medens Indlægene er bevarede.

Dette Testamente har Præsten oprettet i Oktober 1679, det er blevet stadfæstet af Hertug Chrisian Albrecht d. 18. Marts 1681. - Tønder Amt hørte jo til den Gottorpske Del af Slesvig. Da den danske Konge i 1684 inddrog den gottorpske Del, har Præsten fremsendt Testamentet til Kongen, for ogsaa at opnaa den kongelige Stadfæstelse. Denne bevilgedes d. 9. August 1686.

Petrus Claudius indsætter sin Hustru Anna Margaretha Claudii til Enearving, der var ingen Born i AEgteskabet. Prxstens egenhændige Underskrift tyder paa en Mand i sin hedste Alder, den er $i$ hvert Tilfælde ikke skrevet af en Mand paa 80 Aar, som Præsten Petrus Claudius fra Hjerpsted vilde have været i 1679.

Medens den Petrus Claudius, som fik Kaldet i Humptrup ved i 16 ijo at gifte sig med Formandens Enke Cecilia Sønnichsen, ikke kan være Præstesønnen fra Hostrup, men maa være Præsten fra Hjerpsted, som er den eneste, der kan være Tale om, og da denne ikke kan have underskrevet Testamentet, maa vi antage, at der efter Petrus Claudius fra Hjerpsted er fulgt en anden Petrus Claudius som Præst i Humptrup. Denne Petrus Cla11dius, som var gift med Anna Margareta, er sikkert Sønnen af Præsten i Hostrup Paul Claudius, den yngste af Claus Paulsens Sønner fra Emmerlev. Præstekaldene blev saa vidt muligt i Familien. Det var derfor kun naturligt, at Petrus Claudius II (Hostrup) fulgte efter sin Farbroder Petrus Claudius I (Hjerpsted) som Præst i Humptrup. Fædrenekaldet i Hostrup var efter Faderens Død i 1665 overtaget af Svogeren Johannes Mauritius, saa Sønnen var henvist til at søge et Kald andetsteds.

$\mathrm{Nu}$ forstaar vi ogsaa bedre, hvorledes det er kommen, at Præsten i Humptrup Petrus Claudius baade skulde være fra Hostrup, have ægtet Formandens Enke, have levet i $1686^{\circ} \mathrm{og}$ formentlig til 1693, da Hans Hansen fra Flensborg blev Præst i 
Humptrup. Hver af disse Kendsgerninger er rigtig, men de refererer til to Præster af samme Navn, noget, man hidtil ikke har tænkt sig.

En anden af Claus Povlsøns Sønner var Claus Claussøn. I Universitets Matriklen indføres han 12/11 1632 under Navnet Nicolaus Claudii, tilføjet Hjemstedsbetegnelsen Emmerløf. I Præstehistorierne af Wiberg og Arends kaldes han Claus Clausen Emmerlev, idet Emmerlev staar som Familienavn. Da det af hans egne Familieoptegnelser fremgaar, at han kaldte sig Claus Clausson, maa man lade ham beholde Claussøn-Navnet, hvis man ikke af Hensyn til Efterkommerne, som antog Navneformen Claudius, vil kalde ham Claus Claudius.

Hans ældste Søn Claus kaldes i Københavns Universitets Matrikel, hvor han blev indskreven 13/7 1668, Claudius Claudij Emmerlovius. Han aflagde Ed for Bispen i Ribe 18/2 1675 og fungerede som Kapellan hos Faderen indtil sin Død 11/2 1686. Hans Enke giftede sig med Marcus Kiel, som fik Kaldet efter hendes Svigerfaders Død. Claus Claussøn jr. kaldes hos Wiberg lige som Faderen Emmerlev, derfor har Arends opført disse to under Stikordet Emmerlev i Stedet for under Clausen eller Claudius.

Claus Claussøn jr.s Søn Claus, f. $2 / 9$ 1677, immatrikuleres 13/7 1701 ved Københavns Universitet under Navnet Nicolaus Clausen og Hjemstedsbetegnelsen Tondera-Holsatus. I Schous alfabetiske Begister til Universitetets Matrikel er tilføjet i Parentes (Emmerlev). Han havde iforvejen studeret i Leipzig, han er immatrikuleret i Sommeren 1698 som Nic. Clausen, Tonderen. I 1702 blev han cand. theol. i København; i 1707, da han lod sig indskrive i Universitetets Distinktions Protokol, opholdt han sig i Emmerlev. Han var Fadder til sin Broder Hans's Førstefødte: Datteren Anna Sophie, f. 12. Juni 1716. Han er rimeligvis bleven boende i Emmerlev, indtil han i 1724 blev Præst i Hjerpsted.

Broderen Hans er immatrikuleret i København 7/2 1702 under Navnet Johannes Claudius, Emmerlovius, Tundera Holsatus, han havde lige som Broderen studeret $i$ Leipzig og var immatri- 
kuleret samtidig med ham. I Præstekaldsbrevet - at være Capellan og succederende Sognepræst - udstedt af Grev Schack og konflrmeret d. 27. Febr. 1712, benævnes han Hans Clausen. Det er sikkert ham, som har antaget Navnet Claudius som Familienavn, da hans Søn Samuel Nicolaus Claudius, som blev Amtsforvalter i Løgumkloster, kun kendes under Navnet Claudius. Dennes Søn Hans Bachmann Claudius, som fik Leutnants Karakter 10/11 1774, er den sidste, der kendes af Emmerlev Linjen Udover hans Udnævnelse kendes ikke noget til hans Skæbne.

Den 24. December 1651 fødtes Claus Claussøn sen. Sonnen Hans. Denne er sikkert identisk med Johannes Emmerlovius Claudii filius, som 20/7 1670 immatrikuleredes ved Kobenhavns Universitet fra Ribe Latinskole, og med den Hans Clausen, som var Præst i Skast i 1684 og 1(693. I Emmerlev Kirkelog er hans Datter Annas Daab indført d. 12. Juni 1(i84. Slægten Claudius er repræsenteret ved 3 Medlemmer blandt Fadderne.

Claus Povlsøns Søn Jens Claussøn blev Præst i Daler, af hans Sømmer blev Hans, som Moller kalder Johannes Claudius eller Hans Jensen, immatrikuleret Sept. 1660 i Rostock som Johannes Claudius Holsatus, og er sikkert identisk med Johannes Clausenius Holsatus, som 13/5 1662 immatrikuleredes i Wittenberg, han immatrikuleredes i Kiel under Navnet Johannes Claudius 5/10 1667. Samme Aar blev han Præst i Braderup.

Jens Claussøns Søn Claus kaldes af Moller Claus Johannides, han immatrikuleres i Rostock Maj 1661 uden Fornavn som Claudius Thaler Tundera Holsatus. Han blev senere Rektor for Thisted Latinskole, nemlig fra 11. Juli 1685-Marts 1689, da han døde fattig og uden Arvinger. Hundrup kalder ham Claus Dahler.

\section{III.}

I det Kongelige Biblioteks Haandskriftsamling ( $\mathrm{N} \mathbf{~ k g l}$. Samling. 4to 1977 b) findes nogle Optegnelser vedr. Claus Claussøn sen., som sikkert er nedskreven af ham selv. Den ældste bevarede Kirkebog fra Emmerlev begynder i Aaret 16ว0. Disse Op- 
tegnelser vedr. Familiebegivenheder i Præstefamilien gaar dog længere tilbage. For Daabshandlingerne efter 1650 kan det konstateres, at Optegnelserne er overensstemmende med Kirkebogen.

Optegnelserne aftrykkes ordret nedenfor med tilføjede Noter vedr. Fadderne.

In nomine Jesu mei.

Den 23. Januarii imellem 2 oc 3 horis $m$ at $u$ tin is er H. Claus Claussøn forl Anno 1611, nu Sogneprast til Emmerleff Kirke.

Den 17. Februarii Anno $16 ; 36$ er hand indviet oc ordineret $i$ Riber Domkirke af haderlige oc hajlæerd Mand D. Johan Borchardsan til det $H$. prædikeembede at betjene udi Emmerleff Kirke.

Anno 1646 den 4. Sondag effter Trinit. stod hans Bryllup mit hæderlige oc gudfrygtige pige Anna Hans Pederssons Ilaatter aff Tynder oc ere sammenviede aff hæderlige og vellærd Mand $H$. Johannes Clausson, ${ }^{2}$ ) Sognepræst udi Synder Lygom i Kierherrit.

Anno 1647 den 25 . octob. bleff vores lille kiere Søn Claus Claussøn lykkeligen $f(x)$ imellem 9 oc 10 formiddag oc bleff dwht d. 2 . Novemb. Den naadige Gud, lad hannem vare oc bliffe Din Naarlis Kar for Jesu Christi Skyld. Hans Faddere var Asr-oc Velbyrdig Mand Casper Rudolphi von Gerstorff, ${ }^{3}$ ) hans kiere Oldefader Hæderlig oc Vellærd Mand H. Claus Paulssgn. ${ }^{4}$ ) Erlig oc Velact Mand Anders Lund ${ }^{5}$ ) i Højer. Lucie H. Jenssis. $\left.{ }^{0}\right)$ Marie Clausdatter. $\left.{ }^{7}\right)$

Anno 1649 den 1. Martii bleff voris lille kiere Daatter Ingehorg fod $\approx$ Stunde for Dagen oc strax paa Fredag den 2. Martii ved Daaben Jesu Christo indpodit. Jesus velsigne hende. hendis Faddere vare Anders Pederssøn i Kiergaard. Laurits Soffrensøn. Boe Christessøn. Boild Anderskau. Anna (lausdaatter..$^{N}$ Anna Pedersdaatter ${ }^{9}$ ) aff Hierupsted. Anna Michelsdaatter. Hoht af hendes Oldefader.

Anno 1651 den 24 . December som var lige paa en Juleaften bleff voris liden kiere Søn Hans Claussøn foxd en 2 slett offuer Middag oc dixbt den 28. Guid velsigne hannem. Compatres vare min kiere Broder $H æ d$ erligge oc vellærd Mand $H$. Jens Claussen i Daler. Anders Bleg udi Gerup. Peder Michelsøn. Hans kiere Oldemoder aff Tynder Anna Hans Christessons Hustru. Haderlige oc Vellærd Mand H. Lauritz Mauritius i Hierupsted meddelt ham Ilaaben.

Anno 1(x-4) den 10. Augusti ipso die Laurentii bleff voris kiere Søn Peder Clausson fød tilig om Morgenen! Klokken verl 5 slett oc bleff dobt den 16. Augustii. Gud lade Din Aand oc Haand være offuer hannem. Compatres fuere: Haderlige oc Vellard Mand $H$. Povel Claus$\mathbf{s}^{\left(\mathrm{m}^{10}\right)}$ i Hostrup. Hæderlige oc Vellærd Mand H. Lauritz Mauritius

2) Prastens Broder, Prast i S. Lygum 16\%3-49,

3) Ejer af Søndergaarde.

4) Præstens Fader.

5) Herredsfoged i Højer Herred.

B) Præstens Svigerinde, Præsten i Daler Jens Claussøns Hustru.

7) Præstens Søster.

8) Præstens Søster.

9) Prastens Broderdatter.

10) Præstens Broder, Præst i Hostrup 1638-1665. 
udi Hierupsted. Madtz Ibsøn aff Kiergaard. Dydige oc Gudfryctige Quinde Elsbe Mattis Dalers aff Hadersleff. Metta Clausdaatter off Jeissing. Hans Døbefader var Haderlige oc Vellærd Mand H. Peder ${ }^{11}$ ) udi Humtrup.

Anno 16..7 den 27. Januarii 2 Dage effter S. Pouvells Dag bleff voris liden kiere Daatter Agatha Clausdaatter fød oc døbt d. 29. Compatres fuere Hans Pederssøn. ${ }^{2}$ ) Hans H. Jens Claussøns Søn ${ }^{13}$ ) aff Daler. Herlig H. Pouvel Claussøns Hustru ${ }^{14}$ ) aff Hostrup. Øllgaard Bertel Giessenbergs af Tynder. Marie Boe Christessøns aff Hemgaard, hendes Dobefader var Hæderlig oc Vellard Mand D. Laurentius Mauritius Pastor Hierupstediensis. Gud naadeligen hende bevare oc velsigne bode til Liv oc Siel oc det for Christo Skyld. Amen.

Anno 1661 den 23. Decembris Klokken ved 3 efter midnatt bleff voris liden kiere Søn Jens Claussøn fød oc døbt den 27 , paa en tredje Juledag. O Gud styre oc styrke ham med Din H. Aand. Compatres fuere Hæderlige oc Vellærd Mand H. Fgidius ${ }^{15}$ ) ucii Daler, Niels Michelssøn Degn, Hans Tygessøn min Naboe, Marie H. Lauritzis $^{16}$ ) udi Hierupsted, Ølgaar S. H. Jenssis Daatter ${ }^{17}$ ) aff Daler.

\section{IV.}

Nedenfor aftrykkes en Stamtavle over Præsteslægten Claudius, i hvilken kun Præsterne er medtaget og hvor Navneformen Claudius er anvendt for alle Medlemmer.

\footnotetext{
11) Præstens Broder, Præst i Humptrup 1619 1693.

12) Præstens Svoger, gift merd Prastens Søster Marie.

13) Prostens Brodersøn.

11) Præstens Svigerinde.

15) Agidius Nissen Brøns, Praxst i Daler 1660-1675, gift med Ingeborg. Datter af Jens Claussøn i Daler.

16) Præsten Laurits Maritius Hustru.

17) den afdøde Præst i Daler Jens Claussøns Datter.
} 


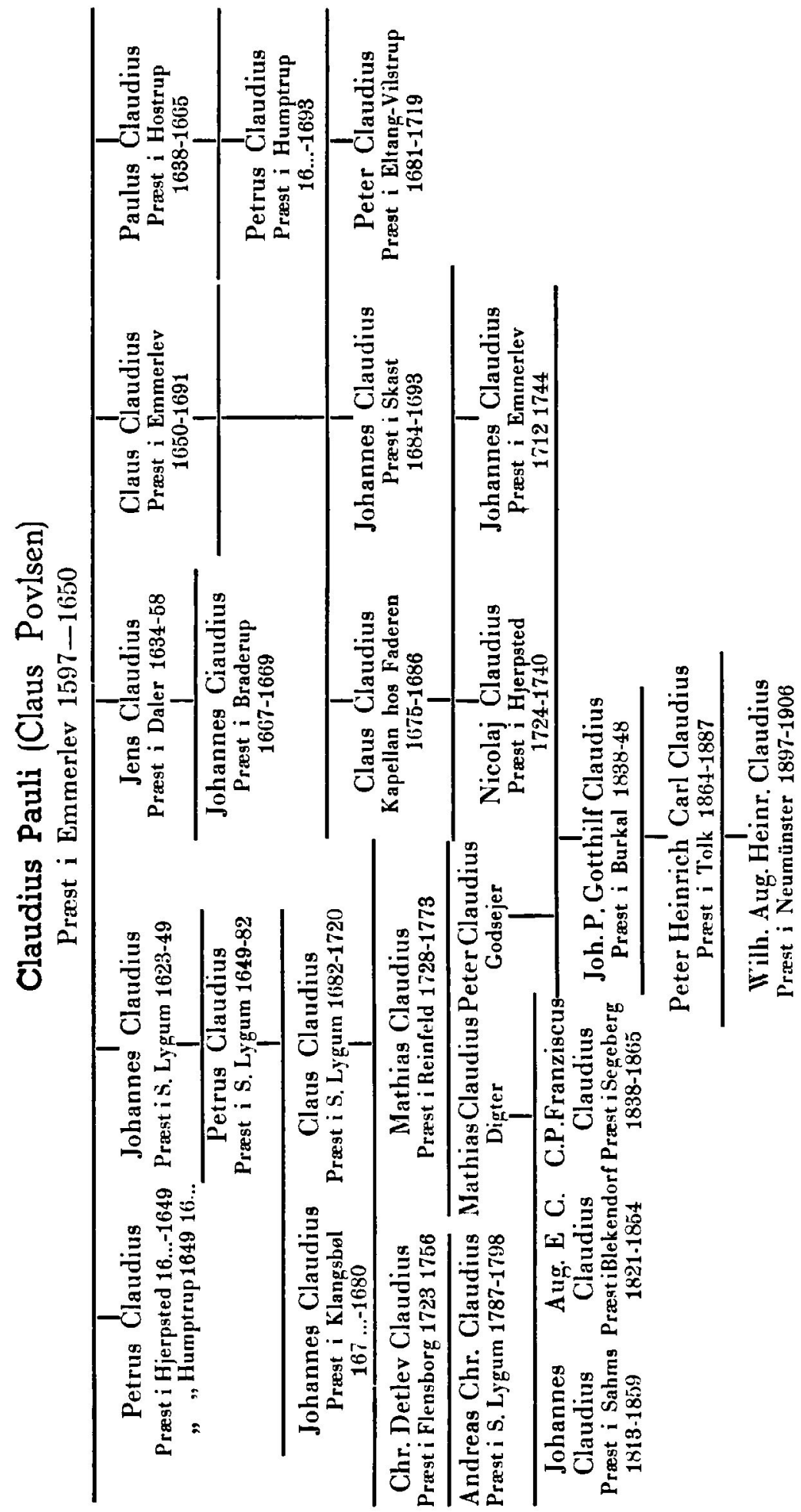

